\title{
KEY FACTORS IN WORKING CAPITAL MANAGEMENT IN THE BRAZILIAN MARKET
}

FATORES DETERMINANTES DA GESTÃO DO CAPITAL DE GIRO NO MERCADO BRASILEIRO FACTORES DETERMINANTES DE LA GESTIÓN DEL CAPITAL DE GIRO EN EL MERCADO BRASILEÑO

\begin{abstract}
Many studies have been conducted in corporate finance regarding long-term investment and financing decisions. However, short-term asset investments play a significant role in the balance sheet of companies. Moreover, financial managers dedicate significant amounts of time and effort to the subject of working capital management, balancing current assets and lia-

bilities. This paper provides insights regarding the key factors of working capital management by exploring the internal variables of a number of companies. This study used data from 2,976 Brazilian public companies from 2001 to 2008, and found that debt level, size and growth rate can affect the working capital management of companies.
\end{abstract}

KEYWORDS Working capital, financial management, panel data, Brazil, liquidity.

Nathalie Vicente Nakamura Palombini npalombini@hotmail.com

Mestre em Administração de Empresas pelo Programa de Pós-Graduação em Administração de Empresas, Universidade Presbiteriana Mackenzie - São Paulo - SP, Brasil

Wilson Toshiro Nakamura wtnakamura@uol.com.br

Professor do Núcleo Permanente do Programa de Pós-Graduação em Administração de Empresas, Universidade Presbiteriana Mackenzie - São Paulo - SP, Brasil

RESUMO Muitos estudos já foram realizados sobre finanças corporativas, com relação a decisões de financiamento e investimento de longo prazo. Porém, os investimentos em ativos de curto prazo desempenham um papel importante no balanço patrimonial das empresas. Além disso, os gestores financeiros dedicam quantidade significativa de tempo e esforço ao tema do gerenciamento do capital de giro, equilibrando realizáveis e exigíveis de curto prazo. Este artigo apresenta insights sobre os fatores determinantes do gerenciamento de capital de giro, explorando variáveis internas de várias empresas. 0 estudo usou dados de 2.976 empresas brasileiras de capital aberto referentes ao período entre 2001 e 2008 e concluiu que o nível de dívidas, o tamanho da empresa e a taxa de crescimento podem afetar a gestão do capital de giro das empresas.

PALAVRAS-CHAVE Capital de giro, gestão financeira, dados em painel, Brasil, liquidez.

Resumen Muchos estudios ya se realizaron sobre finanzas corporativas, con relación a decisiones de financiación e inversión a largo plazo. No obstante, las inversiones en activos a corto plazo desempeñan un papel importante en el balance patrimonial de las empresas. Además, los gerentes financieros dedican cantidades significativas de tiempo y esfuerzo al tema de la administración del capital de giro, equilibrando realizables y exigibles a corto plazo. Este artículo presenta insights sobre los factores determinantes de la administración del capital de giro, explorando variables internas de varias empresas. Este estudio usó datos referentes al período de 2001 a 2008 de 2.976 empresas brasileñas de capital abierto y concluyó que el nivel de deudas, el tamaño de la empresa y la tasa de crecimiento pueden afectar la administración del capital de giro de las empresas.

Palabras clave Capital de giro, factores determinantes, datos en panel, Brasil, liquidez. 


\section{INTRODUCTION}

Any researcher who conducts an overview of the corporate finance literature will find no robust, widely accepted theory about working capital management. So far, few studies have been conducted on this subject compared to long-term corporate finance. Additionally, the majority of related empirical studies have focused on its relationship with company profitability, not on its key factors. Decisions related to working capital management have a direct impact both on liquidity and profitability (APPUHAMI, 2008; SHIN and SOENEN, 1998). According to Brealey, Myers and Allen (2008), there is still little knowledge about the ideal liquidity level, understood as current assets, in order to maximize company value.

Many internal as well as external factors can influence corporate decisions relating to the optimal level of current assets and current liabilities. Among these factors is the influence of corporate financing decisions. One of the most relevant theories about capital structure is the Pecking Order Model, by Myers and Majluf (1984). According to this theory, companies tend to consume financial slack in order to raise internal capital before increasing financial leverage by borrowing money from outside or issuing new stocks.

In order to raise capital for an investment, managers could easily dispose of liquid current assets, adopting an aggressive working capital policy, such as pressuring for lower levels of inventory and decreasing customer credit terms.

Another factor affecting company decisions regarding working capital level could be related to the conflict of interests between managers and shareholders, as examined in the Agency Theory (JENSEN and MECKLING, 1976). In companies with a low level of monitoring and few instruments to discipline management decisions, managers might decide not to invest in projects with a positive net present value, or they might even decide to invest in projects with a negative net present value. Another source of agency problems is the excess of free cash flow, defined by Jensen (1986) as the cash flow beyond what is necessary to finance positive net present value projects. This author affirms that a context of substantial free cash flow makes managers more likely to invest in projects with negative net present value, increasing agency problems between managers and shareholders. Some of these projects and activities "[...] may be self-gratifying to the managers and may bring them some pecuniary benefits or other personal rewards [...]" (CHUNG, MICHAEL and KIM, 2005, p. 55). In other cases, managers could treat investment decisions carelessly, adopting a more flexible working capital policy, with a high level of inventory or a generous credit policy beyond operational needs.

The discussion about the main factors of working capital management is not a simple one. Most studies about working capital management have focused on its relations with company profitability, by assessing the impact of working capital policies on the creation of value to shareholder. The purpose of this study is to examine the main factors of working capital management in order to increase knowledge about corporate finance, especially short-term decision-making, and to improve corporate decision-making. In the international literature, especially major finance and accounting journals, there are few empirical studies testing modern theories about corporate finance in this respect. This study focused on Brazilian companies listed in São Paulo Stock Exchange in the period from 2001 to 2008. We decided to study the Brazilian perspective because so far there are no records of any studies focusing on this specific issue in the Brazilian market. With regards to the country, good management of working capital is clearly relevant to the operational performance of Brazilian Companies, given the high costs of short-term loans and the difficulties to obtain funding for the permanent needs of working capital.

\section{LITERATURE REVIEW AND HYPOTHESES}

Working capital management is a relevant subject to financial managers who dedicate significant amounts of time and effort seeking an ideal balance between risk and return, profitability and liquidity, in order to create value for the company (LAMBERSON, 1995; APPUHAMI, 2008; MARTIN and MORGAN in KIM and SRINIVASAN, 1991). Making decisions about policies, monitoring the performance of each component, as well as taking actions to minimize targets deviations is a frequent, repetitive and time-consuming work (LAMBERSON, 1995, Appuhami, 2008). The lack of understanding about its impact on profitability, the lack of clarity about its key factors, the lack of management ability to plan and control working capital components may lead to insolvency and bankruptcy. Smith (1973) suggested that many businesses have failed due to the inability of financial managers to 
plan and control current assets and current liabilities in their companies. In Brazil, a recent study with 14,181 small companies had the same findings (SEBRAE, 2005). Despite its relevance for business success (FILBECK and KRUEGER, 2005), there are few studies and consolidated theories dedicated to this theme worldwide. Particularly in Brazil, studies have focused on understanding each individual component of working capital and analyzing liquidity risk (FLEURIET, 2003; MARQUES and BRAGA, 1995; LOPES, 2005; MESQUITA, 2008). The following studies were collected from international literature, and they contribute to understand the key factors of working capital management, taking into consideration the combined effect of its main components: inventory, accounts receivable and accounts payable.

Nunn (1981) approached working capital requirements by dividing them into seasonal and permanent necessities (GITMAN, 1997). This author examined the permanent ratio of working capital, i.e. the ratio that does not vary according to short-term changes in the business activities of companies. Using data from different industries, from 1971 to 1978, that study found 19 possible key factors of working capital management, and they were related to production process, sales, accounting method, competitive position and industry factors. Hawawini, Viallet, and Vora (1986) examined data from 1,181 American companies from 36 industries over a 19-year period (1960-1979). These authors found that industry had a significant, persistent effect on the investments of companies, and that this effect was sustained over the time. The study also found industry benchmarks which companies adhered to when setting their working policies on capital investment. Filbeck and Krueger (2005) provided insights to support the relevance of an efficient working capital management, assessing nearly 1,000 companies in United States in the period from 1996 to 2000. Their study found significant differences between industries regarding working capital measures over time, as well as significant changes in those measures within industries over time. The authors suggested that these changes could be related to the macroeconomic factors such as interest rate, innovation rate and competition. Using data from a panel of U.S. corporations from 1990 to 2004, Kieschnick, Laplante and Moussawi (2006) found that industry practices, company size, future sales growth, number of outside directors on the board, executive compensation (current portion), and CEO share ownership have a significant impact on the efficiency of working capital management of companies. Their study suggested that managers responded positively to both incentives and monitoring regarding working capital management. Using economic indicators as independent variables and financial ratios as dependent variables, Lamberson (1995) explored the relationship between changes in working capital position and changes in the level of economic activity, using a sample of 50 U.S. small companies from 1980 to 1991 . His study found that liquidity slightly increased during economic expansions, while no noticeable liquidity change was found during economic slowdowns. Sathyamoorthi and WallyDima (2008) analyzed domestic retail companies listed in Botswana Stock Exchange from 2004 to 2006, and found that companies tended to adopt a conservative approach in times of high business volatility, while an aggressive approach was more likely to be adopted in times of low volatility. Chiou, Cheng and Wu (2006) explored the key factors of working capital management, using 19,180 company-quarter data from Taiwan Stock Exchange in the period from 1996 to 2004. Their study suggested that debt ratio and operating cash flow affected the working capital of companies. On the other side, no evidence was found to support the impact of business cycle, industry effect, company growth, company performance and company size on working capital management. Nazir and Afza (2008) studied the key factors in the requirements of working capital management, using 204 manufacturing companies from 16 industrial groups listed at Karachi Stock Exchange, Pakistan, in the period from 1998 to 2006. These authors found that operating cycle, leverage, ROA and Tobins'Q had a significant impact on working capital requirements. Appuhami (2008) investigated the impact of corporate capital expenses on working capital management, using data collected from listed companies in the Thailand Stock Exchange, from 2000 to 2005. The study found a negative relation with capital expenses, suggesting that companies tended to manage working capital efficiently when they could find opportunities to grow by investing in fixed assets. The study also found a positive, significant relation between working capital requirements and operating and finance expenses, suggesting that companies tended to increase their working capital levels as debt and interest expenses increased.

A summary of the independent variables in each study, including their hypotheses and findings, is shown in Exhibit 1.

\section{Pecking order theory}

The Pecking Order Theory takes into consideration 
the information asymmetry that suggests that managers know more about the value of their company than potential investors (MYERS and MAJLUF, 1984). This information asymmetry affects the choice between internal and external financing. Based on this concept, the Pecking Order Theory states that companies tend to rely on internal funds to finance themselves, prefer- ring to issue debt to equity when external financing is required (MYERS and MAJLUF, 1984). According to Nakamura and others (2007, p.76), this order is based on the assumption that "[...] resources generated internally do not have transaction costs, and issuing new bonds tends to signal positive information about the company, while issuing new shares, on the contrary,

\section{Exhibit 1 - Summary of independent variables, hypotheses and findings of the literature review}

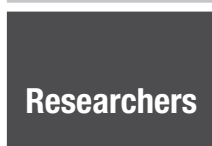

Nunn (1981)

Hawawini,

Viallet and

Vora (1986)

Kieschnick, Laplante and

Moussawi

(2006)

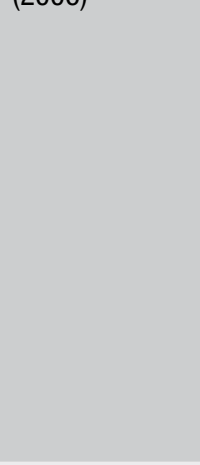

Lamberson

(1995)

\section{Dependent variable proxies- \\ Working Capital Management}

Permanent working capital/sales

Working capital requirement-to-sales ratio

Logarithm of cash
Conversion Cycle

Industry practices

Company size

fixed assets ratio

Company sales growth

Market power (Herfindahl-Hirschman index)

Board characteristics measured by number of directors

Board characteristics measured by ratio of outside members

CEO compensation measured by total current compensation (stock options excluded)

CEO compensation measured by CEO total unexercised stock options.

Ratio of CEO-held stock

Governance index (provisions)

Economic activity

Quick ratio

Inventory/asset

Current asset/asset

\begin{tabular}{c|l}
$\begin{array}{c}\text { Hypotheses: } \\
\text { coefficient } \\
\text { sign: }\end{array}$ & $\begin{array}{c}\text { Findings: } \\
\text { coefficient } \\
\text { sign }\end{array}$ \\
+ & + significant \\
- & - significant \\
- & - significant \\
+ & + significant \\
+ & + significant \\
- & - significant \\
+ & + significant \\
+ & + significant
\end{tabular}

No significant No significant differences differences

$+\quad+$ significant

$+\quad$ - not significant

$+\quad+$ significant

- not significant

- $\quad$ - not significant

- $\quad$ - significant

- significant

- significant

- not significant

- + significant

- $\quad+$ not significant

- $\quad+$ not significant

- $\quad+$ significant

$+\quad$ - significant

$+\quad$ - not significant 


\begin{tabular}{|c|c|c|c|c|}
\hline $\begin{array}{l}\text { Filbeck and } \\
\text { Krueger } \\
\text { (2005) }\end{array}$ & $\begin{array}{l}\text { Cash conversion } \\
\text { consistency, days } \\
\text { of working capital, } \\
\text { inventory turnover } \\
\text { and payables, CFO's } \\
\text { overall ranking. }\end{array}$ & $\begin{array}{l}\text { Industry significance: working capital measures of different } \\
\text { industries over time. } \\
\text { Period consistency: Working capital measures within industries } \\
\text { over time }\end{array}$ & $\begin{array}{l}\text { significant } \\
\text { differences } \\
\text { significant } \\
\text { differences }\end{array}$ & $\begin{array}{l}\text { significant } \\
\text { differences } \\
\text { significant } \\
\text { differences }\end{array}$ \\
\hline $\begin{array}{l}\text { Chiou, Cheng } \\
\text { and Wu. } \\
\text { (2006) }\end{array}$ & $\begin{array}{l}\text { Working capital } \\
\text { requirement/ total } \\
\text { assets }\end{array}$ & $\begin{array}{l}\text { Business indicator measured by business cycle during recession } \\
\text { Business indicator measured by business cycle } \\
\text { Industry effect } \\
\text { Debt ratio } \\
\text { Operating cash flow } \\
\text { Growth opportunity } \\
\text { Company age } \\
\text { Company performance } \\
\text { Company size }\end{array}$ & $\begin{array}{c}+ \\
- \\
\text { significant } \\
\text { differences } \\
- \\
- \\
- \\
+ \\
- \\
+\end{array}$ & $\begin{array}{l}\text { - significant } \\
\text { - significant } \\
\text { no evidence } \\
\text { found } \\
\text { - significant } \\
\text { - significant } \\
\text { - not significant } \\
\text { + significant } \\
\text { + significant } \\
\text { + significant }\end{array}$ \\
\hline $\begin{array}{l}\text { Nazir and Afza } \\
\text { (2008) }\end{array}$ & $\begin{array}{l}\text { Working capital } \\
\text { requirement/ total } \\
\text { assets }\end{array}$ & $\begin{array}{l}\text { Operating cycle } \\
\text { Operating cash flows } \\
\text { Level of economic activity } \\
\text { Sales growth of the company } \\
\text { Return on assets } \\
\text { Tobin's Q } \\
\text { Financial leverage } \\
\text { Company size } \\
\text { Industry Dummy }\end{array}$ & $\begin{array}{l}+ \\
+ \\
- \\
-\end{array}$ & $\begin{array}{l}\text { + significant } \\
\text { + not significant } \\
\text { + not significant } \\
\text { + not significant } \\
\text { + significant } \\
\text { + significant } \\
\text { - significant } \\
\text { + not significant } \\
\text { + significant }\end{array}$ \\
\hline $\begin{array}{l}\text { Appuhami } \\
\text { (2008) }\end{array}$ & $\begin{array}{l}\text { Working capital } \\
\text { requirements }\end{array}$ & $\begin{array}{l}\text { Capital expense } \\
\text { Operating expense } \\
\text { Finance expense } \\
\text { Operating cash flow (control) } \\
\text { Sales growth of the company (control) } \\
\text { Company performance (control) } \\
\text { Financial leverage (control) }\end{array}$ & $\begin{array}{l}- \\
- \\
-\end{array}$ & $\begin{array}{l}\text { - significant } \\
\text { + significant } \\
\text { + significant } \\
\text { - significant } \\
\text { + not significant } \\
\text { + not significant } \\
\text { + not significant }\end{array}$ \\
\hline
\end{tabular}

tends to signal negative information". According to this point of view, companies do not pursue specific objectives regarding debt level; they use external funds only when internal funds are not enough (GRAHAM and HARVEY, 2001). External sources of funds are less desirable because this manager-investor information asymmetry implies that external sources of funds are underpriced in relation to the level of asymmetry (MYERS and MAJLUF, 1984). According to Chen (2004), this theory explains why companies choose to keep reserves in cash or other forms of financial slack - to avoid both lack of resources and the need for external sources. According to this point of view, cash is similar to "negative debt"; external resources are sought when there is a cash shortage; and debts are paid when there is an excess of cash. Therefore, the company chooses a more passive cash management policy, waiting to settle existent debts whenever further costs are not involved (KOSHIO, 2005).

Financial slack is the result of large withholdings of cash or marketable securities, or the ability to issue default risk-free debt beyond what is necessary to meet current operating and debt servicing needs (MYERS and MAJLUF, 1984; BREALEY, MYERS and ALLEN, 
2008; McMAHON, 2006). Companies choose conservative financing in order to have easy access to the debt market and lead potential investors to see them as a safe investment. According to Smith and Kim (1994) and McMahon (2006), adequate levels of financial slack allow companies to pursue investment opportunities with positive net present value without issuing risky securities. The conventional rationale for withholding financial slack - cash, liquid assets or unused borrowing power - is that the companies seek to avoid the necessity to issue shares on short notice in order to pursue a valuable investment opportunity (MYERS and MAJLUF, 1984).

Brealey, Myers and Allen (2008) suggested that the Pecking Order Theory explains why profitable companies are less likely to borrow - not because they have low debt targets but because they do not need funding from external sources. Less profitable companies, contrarily, issue bonds because they do not have enough internal funds to finance investment decisions. Therefore these companies also prefer to issue debts before issuing new shares. According to this theory, managers from less profitable and highly profitable companies alike would choose a more aggressive working capital policy, pressuring for lower levels of current assets and higher levels of financing from suppliers, resorting to internal sources for the necessary funds to finance their companies and to avoid issuing debt and equity. The purpose of the first hypothesis of this study is to understand whether companies with a high level of debt also have a low level of working capital reflected in a low level of inventory, low credit terms and high payment terms, due to the choice of managers for an aggressive working capital management in order to avoid issuing new debt and equity.

Hypothesis 1: There is a negative relationship between the debt level of a company and its working capital level.

\section{The Agency theory}

According to the Agency Theory (JENSEN and MECKLING, 1976), a company can be considered the nexus of a set of contract relationships (both implicit and explicit ones) among individuals, by which shareholders - principals - delegate everyday decisions of business management to managers - agents - who should use their specific knowledge and the resources of the company to maximize returns for principals. In these contracts, or internal "rules of the game", shareholders specify "[...] the rights of each agent in the organization, the performance criteria on which agents are evaluated, and the payoff functions they face [...]" (FAMA and JENSEN, 1983, p. 2). Due to a non-rational, opportunistic behavior of agents (JENSEN, 1994), the interests and decisions of managers are not always aligned to those of the shareholders, which causes agency costs or agency problems. For Shleider and Vishny (1997), the essence of agency problem is the separation of ownership and control. In large and complex organizations, these problems can be easily found, since the valuable, specific knowledge required to control decisions is diffused among many internal agents across the company (FAMA and JENSEN, 1983). In this case, owners are unable to participate in the ratification and monitoring of each decision due to the high costs associated to it. Jensen and Meckling (1976) defined agency cost as the sum of the monitoring expenses incurred by principal, the bonding expenses incurred by agents and the inevitable residual loss derived from the separation of ownership and control.

In order to minimize interest divergences, principals can establish incentives, monitoring mechanisms and instruments to make sure that agents will not take actions that jeopardize their interests, or to be compensated ("bonding costs") in case of agency problems. Fama and Jensen (1983) suggested that the agency problems could be minimized by separating the ratification and monitoring of decisions from their initiation and implementation. Therefore, organizations should rely on decision control systems such as a formal decision-making hierarchy, a mutual monitoring system and an active board of directors. Weir and Laing (2003) distinguished three mechanisms designed to protect shareholder interests: incentive, monitoring and disciplinary mechanisms. Incentive mechanisms include executive director shareholding or board compensation systems (JENSEN e MECKLING, 1976); monitoring mechanisms include, for example, the ratio of outside directors in the board (Fama, 1980; Fama and Jensen, 1983); and disciplinary mechanisms include the market for corporate control (JENSEN, 1986). Shareholders design monitoring devices in order to align the actions of agents to their interests (FAMA, 1980). According to Tirole (2005), monitoring systems include a variety of instruments such as board composition, auditors, large shareholders, large creditors, investment banks, etc.

Deciding the way to invest internal funds is central in shareholders and managers conflicting interests 
(JENSEN, 1986). According to Easterbrook (1984), when managers have a substantial part of their capital or wealth allocated in shares of the company, they tend to take decisions to enhance its probability and survival. These decisions can lead to a conservative management of working capital by reducing the risk involved in the operation of the business, e.g., by keeping high levels of inventory beyond process cycle necessities, offering credit terms above product turnover, accepting low payment terms that are not aligned to market practices, etc. In this case, these investment decisions would translate into an excess of working capital. Therefore, the second hypothesis of this study aims to investigate whether companies under monitoring mechanisms of managers have lower levels of working capital requirement.

Hypothesis 2: There is a negative relationship between management monitoring mechanisms and working capital level.

According to Jensen (1986), managers with substantial free cash flow tend to feel encouraged to engage the company in unnecessary expenses. He defined free cash flow as the excess of cash flow beyond the necessary to fund all projects with positive net present values, when discounted at the relevant cost of capital. In organizations with low level of monitoring or discipline over management actions, a high level of free cash flow may encourage managers to follow their own interests and undertake negative present value capital projects rather than return cash to equity holders (MCMAHON, 2006). Jensen (1986) suggests that managers tend to invest free cash flow in new projects because they are motivated to lead their companies to grow beyond optimal size. Company growth increases the power of managers by increasing the resources under their control, which is also associated with increased manager compensation, commonly linked to sales. According to McMahon (2006, p. 15), "[...] retaining free cash flow is essentially a negative net present value investment in liquidity [...]". Therefore, companies with high a level of free cash flow may have higher agency costs derived from organizational inefficiencies or investments with negative returns. The third research hypothesis aims to explore if companies with high levels of free cash flow also have high levels of working capital, represented by an excessive difference between current assets and liabilities as a result of ineffective policy and more conservative use of working capital management.
Hypothesis 3: There is a positive relationship between the level of free cash flow and the level of working capital.

\section{METHODOLOGY}

\section{Sample and data collection}

The present study is partly an exploratory research, although it was based on consolidated theories of corporate finance. In order to address its hypotheses, this study considered the listed companies in São Paulo Stock Exchange as its population. Secondary data were collected from 357 public companies for the period from 1994 to 2008, excluding companies in the financial service industry, from Economática Pro ${ }^{\circledR}$ and DIVEXT B\&MF BOVESPA. All financial data were adjusted according to IPCA/ IBGE inflation indices. In order to obtain a balanced panel, missing data were eliminated, which led to a sample of 120 companies for the period from 2001 to 2008. In addition, this study eliminated the effect of outliers by analyzing key tests conducted using econometric software. The final sample size focused 93 companies during 32 quarters, for the period from 2001 to 2008.

Before discussing the variables of this study, it is noteworthy that there is no consolidated theory about working capital management, which will probably be designed in the future. However, the model used in this study is based on several theories of corporate finance; our model is in line with the study by Hill, Kelly and Highfield (2010), which is based on the United States corporate context.

\section{Dependent variable: working capital management}

This study measured working capital management using the concept of cash conversion cycle (CCC), also known as cash cycle, which was used in many studies (DELOOF, 2003; LAZARIDIS and TRYFONIDIS, 2006; BRIGHAM and EHRHARDT, 2002). Cash conversion cycle measures the period of time in days between the payment for raw materials and the receivables of finished product sales [number of days of accounts receivable + number of days of inventory - number of days of accounts payable]. Cash conversion cycle combines the working capital components related to operational processes, reflecting the purchasing, production and sales processes. (HAWAWINI, 
VIALLET and VORA, 1986). Additionally, we studied other proxies for working capital management, in order to separately explore working capital components: days of accounts receivable (D_AR), days of inventory (D_IN) and days of accounts payable (D_AP). The study chose to calculate them based on Shin and Soenen definition (1998). The number of days of accounts receivable was calculated as [account receivable $\mathrm{x} 365 \mathrm{]} / \mathrm{sales}$. The number of days inventories was calculated as [inventories x 365]/ Sales. The number of days accounts payable was calculated as [accounts payable x 365]/ sales. We also included working capital requirement (WCR), as a fifth proxy, calculated by [accounts receivable + inventory]/ [total assets - financial assets]. Financial assets were excluded in order to remove the effect of shares of other companies unrelated to the operational activities of the studied companies (DELOOF, 2003). Like cash conversion cycle, working capital requirement is also a measure for investment in working capital.

\section{Independent variable: debt level}

Nazir and Afza (2008) and Chiou, Cheng and Wu (2006) measured debt level according to debt ratio leverage calculated as total liabilities divided by total assets. Apphumani (2008) measured leverage as total long-term debt capital divided by equity. In this study, debt level (DEBT) was measured as long term debt divided by total assets.

\section{Independent variable: management monitoring mechanisms}

The concept of corporate governance is based on the agency theory, relying on the assumption that managers do not always act according to the shareholders interests (BECHT, BOLTON and ROELL, 2003 and TIROLE, 2005). Becht, Bolton and Roell (2003) proposed five mechanisms to minimize agency conflicts: (1) board election to represent shareholders interests; (2) hostile takeovers or dispute for vote representation by a large shareholder; (3) active and frequent monitoring by a large shareholder or an intermediate financial part (banks, holding companies or pension funds); (4) alignment of managers interests using compensation contracts; and, (5) clear CEO fiduciary duties either to avoid corporate decisions against shareholders interests or to compensate them for damaging actions.

This study focuses on three key monitoring mechanisms of working capital management: board composi- tion, ownership concentration by large shareholders, and management compensation. The presence of outside directors decreases the probabilities of collusive arrangements and expropriation of shareholder wealth (FAMA, 1980). Board composition was measured according to the participation of outside directors (OUTDIR), calculated by the number of outside directors divided by total directors. Management monitoring by large investors (ownership concentration) was measured using a dummy variable (CONC) that assumed ownership concentration to occur when one investor owned over $20 \%$ of the shares of a company, according to the studies by Pedersen and Thomsen (1997) and Siqueira (1998). Management monitoring using management compensation was measured by a dummy variable (COMP) which indicates annual compensation connected to company profits.

\section{Independent variable: free cash flow}

This study measured free cash flow using a measure applied by Lehn and Poulsen (1989) which was also used by Rahman and Mohd-Saleh (2008). The calculation is shown in equation 1 below:

$$
F C L=(I N C-T A X-I N T E X P-P S D I V-C S D I V) / T A
$$

where: $\mathrm{FCL}=$ free cash flow; $\mathrm{INC}=$ operating income before depreciation; TAX = total taxes; INTEXP $=$ interest expenses; PSDIV $=$ preferred share dividends; CSDIV = common share dividends; and, $\mathrm{TA}=$ total assets at beginning of fiscal year. We measured free cash flow using the logarithm of the equation above.

\section{Control variables}

Large companies are able to make large investments in working capital since they can use their market power to bargain with suppliers and have their payment terms decreased (KIESCHNICK, LAPLANTE and MOUSSAWI, 2006). Company size (SIZE) was calculated using the logarithm for company sales (DELOOF, 2003).

Prior studies (NUNN, 1981; HAWAWINI, VIALLET and VORA, 1986; KIESCHNICK, LAPLANTE and MOUSSAWI, 2006; NAZIR and AFZA, 2008) suggested that working capital practices may differ among industries. Consequently, it was important to control for the impact of industry practices on a study about the key factors of working capital management practices. This study 
used dummies for the three main economy sectors: industry (IND), commerce (COM) and services and other industries $(\mathrm{OTH})$.

Sales growth, which can also represent future growth opportunities, can have an impact on working capital management since managers can decide to prepare the company to meet a different demand level, such as building up inventories for future sales growth (NUNN, 1981; KIESCHNICK, LAPLANTE and MOUSSAWI, 2006). The sales growth variable (GROWTH) was measured by [this year's sales - previous year's sales]/previous year's sales (DELOOF, 2003; NAZIR e AFZA, 2008; APPUHAMI, 2008). It is noteworthy that other studies replaced this variable by Tobin's Q as a measure of growth opportunities; we chose not to use it due to limitations related to this index in Brazilian companies. One of the reasons is the low liquidity of many shares in the Brazilian market.

\section{Model specification}

This study used panel data models consisting of a time series for each cross-section member in the data panel (WOOLDRIDGE, 2002). According to Baltagi (2008), panel data allow researchers to obtain reliable estimates and to find and estimate effects that pure cross-sections and time-series data cannot detect; moreover, panel data do not require restrictive assumptions. This study conducted the following tests: static panel data of fixed effects, static panel data of random effects, dynamic panel data, pooled ordinary least squares (OLS) and feasible generalized least squares (FGLS). We processed the panel data models and conducted the key tests of this study using the econometrics software GRETL 1.8.5, which is distributed as a free package.

Equation 2 considers cash conversion cycle as a proxy for a dependent variable, in the form of a fixed effects static model and it can illustrate the models used in this study.

$$
\begin{aligned}
& C C_{i t}=\beta_{1}+\beta_{2} D_{E B T_{i t}}+\beta_{3} \text { OUTDIR }_{i t}+\beta_{4} \text { CONC }_{i t} \\
& +\beta_{5} \text { COMP }_{i t}+\beta_{6} \text { CCF }_{i t}+\beta_{7} \text { SIZE }_{i t}+\beta_{8} \text { GROWTH }_{i t} \\
& +\beta_{9} I N D_{i t}+\beta_{10} \text { COM }_{i t}+\varepsilon_{i}+\mu_{i t}
\end{aligned}
$$

Where: $\mathrm{i}=1, \ldots, \mathrm{N},=$ company; $\mathrm{t}=1, \ldots, \mathrm{T}=$ time; $\mathrm{CCC}=$ cash conversion cycle; DEBT $=$ debt level; OUTDIR $=$ outside directors participating in the board; CONC = dummy for ownership concentration; COMP =dummy for annual compensa- tion linked to profit; $\mathrm{FCF}=$ free cash flow; SIZE $=$ company size; GROWTH = company growth; IND = dummy for industry; COM = dummy for commerce; $\mathrm{OTH}=$ dummy for other industry sectors (not appearing in the equation because it is the omitted variable); $\beta=$ regression parameter; and, $\mu=$ residual error.

Exhibits 2 and 3 show a summary of the hypotheses, proxies for dependent variables, independent variables, control variables and expected relations in this study.

\section{RESULTS}

We calculated the ordinary least square multiple linear regressions, then tested them for multicollinearity and serial correlation. With regards to multicollinearity, the variance inflation factor (VIF) was calculated, and no multicollinearity was found. We also used the Pearson correlation coefficient matrix and found low correlation coefficients for all independent variable proxies; therefore, no multicollinearity problems were found.

The null hypothesis for homocedasticity was rejected using White's Test. Therefore, the multiple linear regression of feasible generalized least squares (FGLS) was applied to correct the heterocedasticity problem. Next, the multiple linear regressions for both dynamic and static panel data (with fixed and random effects) were calculated. A total of 15 regression equations where included in the results of relations between working capital management proxies, independent variable proxies and control variables. Three tests were conducted, and their results used as the basis to compare the regression equations with regard to their explaining power. The first test was conducted in order to choose between the ordinary least squares model and the fixed effect panel data model. All models presented results that excluded the hypothesis of ordinary least squares. The second test, the Lagrange multiplier test of BreuschPagan, was conducted in order to test for an unobserved effect (WOOLDRIDGE, 2002). All results excluded the hypothesis of random effect explanatory power. The third was the Haussmann test, which compares fixed and random effects estimators, excluding the hypothesis of random effect. Therefore, the fixed effect model was found to have more explanatory power over the key factors of working capital compared to the others, 
suggesting that intercepts vary between companies, but not over time. Table 1 shows a summary of the results of the fixed effects model.

\section{Debt level}

A significant negative relation was found between independent variable debt level (DEBT), cash conversion

\section{Exhibit 2 - Summary of variables, proxies and expected signs of the problematic key factors of working capital management in this study}

\begin{tabular}{|c|c|c|c|c|c|}
\hline & $\begin{array}{l}\text { Proxies for dependent variable } \\
\text { working capital management }\end{array}$ & $\begin{array}{l}\text { Independent } \\
\text { variables }\end{array}$ & $\begin{array}{l}\text { Proxies for inde- } \\
\text { pendent variables }\end{array}$ & Formulas & $\begin{array}{l}\text { Expected } \\
\text { sign }\end{array}$ \\
\hline $\mathrm{H} 1$ & $\begin{array}{l}\text { CCC: Cash Conversion Cycle } \\
\text { WCR: Working Capital Requirement } \\
\text { D_AR: Days of Accounts Receivable } \\
\text { D_IN: Days of Inventory } \\
\text { D_AP: Days of Accounts Payable }\end{array}$ & Debt level & $\begin{array}{l}\text { DEBT: Total debt level } \\
\text { at book value }\end{array}$ & $\begin{array}{l}=[\text { total liabilities }] / \text { total } \\
\text { assets }\end{array}$ & $\begin{array}{l}- \\
- \\
- \\
- \\
+\end{array}$ \\
\hline $\mathrm{H} 2$ & $\begin{array}{l}\text { CCC: Cash Conversion Cycle } \\
\text { WCR: Working Capital Requirement } \\
\text { D_AR: Days of Accounts Receivable } \\
\text { D_IN: Days of Inventory } \\
\text { D_AP: Days of Accounts Payable } \\
\text { CCC: Cash Conversion Cycle } \\
\text { WCR: Working Capital Requirement } \\
\text { D_AR: Days of Accounts Receivable } \\
\text { D_IN: Days of Inventory } \\
\text { D_AP: Days of Accounts Payable } \\
\text { CCC: Cash Conversion Cycle } \\
\text { WCR: Working Capital Requirement } \\
\text { D_AR: Days of Accounts Receivable } \\
\text { D_IN: Days of Inventory } \\
\text { D_AP: Days of Accounts Payable }\end{array}$ & $\begin{array}{l}\text { Management } \\
\text { monitoring } \\
\text { mechanisms }\end{array}$ & $\begin{array}{l}\text { OUTDIR: Participation } \\
\text { of outside directors } \\
\text { in the board } \\
\text { CONC: Presence of } \\
\text { ownership concen- } \\
\text { tration } \\
\text { COMP: Presence of } \\
\text { annual compensation } \\
\text { connected to profit }\end{array}$ & $\begin{array}{l}\text { = Dummy of annual } \\
\text { management compensa- } \\
\text { tion connected to profit }\end{array}$ & $\begin{array}{l}- \\
- \\
- \\
- \\
+ \\
- \\
- \\
- \\
- \\
+ \\
- \\
- \\
- \\
- \\
+\end{array}$ \\
\hline H3 & $\begin{array}{l}\text { CCC: Cash Conversion Cycle } \\
\text { WCR: Working Capital Requirement } \\
\text { D_AR: Days of Accounts Receivable } \\
\text { D_IN: Days of Inventory } \\
\text { D_AP: Days of Accounts Payable }\end{array}$ & Free Cash Flow & FCL: Free cash flow & $\begin{array}{l}=\text { Log [Free Cash Flow/ } \\
\text { total assets] }\end{array}$ & $\begin{array}{l}+ \\
+ \\
+ \\
+ \\
-\end{array}$ \\
\hline
\end{tabular}

\section{Exhibit 3 - Summary of control variables}

\begin{tabular}{l|l}
\multicolumn{1}{|c|}{ CONTROL VARIABLES } & \\
\hline SIZE: company size & $=$ Log [total sales] \\
\hline GROWTH: Sales growth & $=$ [this year's sales - previous year's sales]/previous year's sales \\
\hline IND, COM, OTH & $=$ Dummy for economy sectors
\end{tabular}


cycle (CCC) and working capital requirement (WCR) - different measures for investment of working capital. This finding is consistent with the Pecking Order Theory, which is reflected in the first hypothesis of this study; it is also consistent with the studies by Chiou, Cheng and Wu (2006) and Nazir and Afza (2008). It suggests that companies with a high debt leverage choose a more efficient management of working capital in order to avoid issuing new bonds and shares. This interpretation is reinforced by the analysis of debt effects over days of inventory (D_IN), suggesting that companies with an increased debt level tend to work with a low inventory level. The significant, positive relationship with days of accounts payable suggests that significantly leveraged companies tend to negotiate for increased payment terms with suppliers. With regard to the variable days of accounts receivable, the significant, positive result found suggests that companies with high debt levels normally have high credit terms.

\section{Management monitoring mechanisms}

The second hypothesis of this study aimed to explore the monitoring mechanisms over managers decisions as key factors of working capital management. None of the proxy relations found were statistically significant except for two, namely, the participation of outside directors in the board (OUTDIR) and working capital requirement (WCR). However, the positive result was contrary to our expectations, suggesting that a larger presence of outside directors could not minimize agency costs, as found by Kieschnick, Laplante and Moussawi (2006). Despite our intention to measure the impact of management monitoring mechanisms on working capital management, our findings were inconclusive. This is probably due to the fact that the public data available are still insufficient to be considered as proxies for this independent variable in Brazil.

\section{Table 1 - Multiple linear regression in panel data for generalized least squares with fixed effects}

\begin{tabular}{|c|c|c|c|c|c|}
\hline & \multicolumn{5}{|c|}{ Dependent variable's proxies } \\
\hline & CCO & WCR & D_AR & D_IN & D_AP \\
\hline \multicolumn{6}{|l|}{ Independent variables and proxies } \\
\hline Debt & $\begin{array}{l}-53.928 \\
(-2.304)^{\star \star}\end{array}$ & $\begin{array}{c}-0.221 \\
(-4.911)^{\star \star \star}\end{array}$ & $\begin{array}{c}49.950 \\
(1.698)^{\star}\end{array}$ & $\begin{array}{l}-19.599 \\
(-1.958)^{\star}\end{array}$ & $\begin{array}{c}84.279 \\
(3.982)^{\star \star \star}\end{array}$ \\
\hline Free cash flow & $\begin{array}{c}-4.390 \\
(-1.754)^{*}\end{array}$ & $\begin{array}{l}-0.004 \\
(-1.490)\end{array}$ & $\begin{array}{l}-2.798 \\
(-1.282)\end{array}$ & $\begin{array}{c}-2.568 \\
(-3.660)^{\star \star \star}\end{array}$ & $\begin{array}{c}-0.975 \\
(-0.8913)\end{array}$ \\
\hline \multicolumn{6}{|c|}{ Management monitoring mechanisms } \\
\hline Presence of ownership concentration & $\begin{array}{l}-24.647 \\
(-0.9635)\end{array}$ & $\begin{array}{c}0.020 \\
(1.263)\end{array}$ & $\begin{array}{l}-14.377 \\
(-0.840)\end{array}$ & $\begin{array}{l}-24.962 \\
(-1.069)\end{array}$ & $\begin{array}{l}-14.692 \\
(-1.015)\end{array}$ \\
\hline $\begin{array}{l}\text { Participation of outside directors in } \\
\text { the board }\end{array}$ & $\begin{array}{c}5.520 \\
(1.007)\end{array}$ & $\begin{array}{c}0.024 \\
(2.602)^{\star \star \star}\end{array}$ & $\begin{array}{c}3.972 \\
(0.8802)\end{array}$ & $\begin{array}{c}-1.772 \\
(-0.4858)\end{array}$ & $\begin{array}{l}-3.320 \\
(-0.8617)\end{array}$ \\
\hline $\begin{array}{l}\text { Presence of annual compensation } \\
\text { connected to profit }\end{array}$ & $\begin{array}{l}-9.810 \\
(-1.526)\end{array}$ & $\begin{array}{c}-0.002 \\
(-0.1544)\end{array}$ & $\begin{array}{c}0.156 \\
(0.0454)\end{array}$ & $\begin{array}{l}-7.390 \\
(-1.374)\end{array}$ & $\begin{array}{c}2.577 \\
(0.5509)\end{array}$ \\
\hline \multicolumn{6}{|l|}{ Control variables } \\
\hline Company size & $\begin{array}{l}-39.481 \\
(-1.565)\end{array}$ & $\begin{array}{c}0.062 \\
(1.546)\end{array}$ & $\begin{array}{c}-55.933 \\
(-2.591)^{\star \star \star}\end{array}$ & $\begin{array}{c}-28.468 \\
(-1.670)^{*}\end{array}$ & $\begin{array}{c}-44.920 \\
(-2.594)^{\star \star \star}\end{array}$ \\
\hline Company growth & $\begin{array}{c}-19.046 \\
(-2.769)^{\star \star \star}\end{array}$ & $\begin{array}{c}-0.0004 \\
(-0.03192)\end{array}$ & $\begin{array}{c}-27.030 \\
(-3.945)^{\star \star \star}\end{array}$ & $\begin{array}{c}-11.155 \\
(-2.787)^{\star \star \star}\end{array}$ & $\begin{array}{c}-19.139 \\
(-3.005)^{\star \star \star}\end{array}$ \\
\hline Constant & $\begin{array}{c}308.384 \\
(2.606)^{\star \star \star}\end{array}$ & $\begin{array}{c}-0.084 \\
(-0.4058)\end{array}$ & $\begin{array}{c}373.568 \\
(3.536)^{\star \star \star}\end{array}$ & $\begin{array}{c}224.314 \\
(2.973)^{\star \star \star}\end{array}$ & $\begin{array}{c}289.498 \\
(3.470)^{\star \star \star}\end{array}$ \\
\hline Number of observations & 1409 & 1409 & 1409 & 1409 & 1409 \\
\hline Adjusted R2 & 0.74 & 0.07 & 0.73 & 0.76 & 0.64 \\
\hline
\end{tabular}

Note: t-test in parentheses: ${ }^{* \star}$ Significant at $1 \%$ level, ${ }^{\star \star}$ Significant at $5 \%$ level, * Significant at $10 \%$ level. 


\section{Free cash flow}

The third hypothesis of this study aimed to investigate whether companies with large free cash flow also had a high level of working capital, understood as higher inventories and a more generous credit policy. A negative, statistically significant relationship between free cash flow (FCF) and the variables cash conversion cycle (CCC) and days of inventory (D_IN) was found. These findings are contrary to our expectations. A possible interpretation is the impact of profitability on the composition of the free cash flow formula. The variable profitability could be a key factor of working capital management to be tested in future empirical studies.

\section{Control variables}

Company size (SIZE) was found to be both strongly and negatively related to days of inventory (D_IN). This suggests that large companies do not need to build large inventories proportionally to sales increase, or that large companies can coordinate their supply chain more efficiently than small ones. Days of accounts receivable (D_AR) was also negatively associated with company size, indicating that large companies work with lower receivable terms, which could be explained by their market power. Similar results, although not statistically relevant, were found for the variable cash conversion cycle (CCC). These results were contrary to the studies by Chiou, Cheng and Wu (2006); and, Kieschnick, Laplante and Moussawi (2006), which found working capital inefficiencies to be positively correlated to company size. A negative, significant relationship was found between Days of accounts payable (D_AP) and company size, suggesting that large companies normally wait less to settle their debts.

A negative relation was found between company growth (GROWTH) and working capital management, suggesting that lower growth companies invest more in working capital. One possible reason is that companies with a high growth level have higher internal funds to finance their growth, as proposed by the Pecking Order Theory.

Due to a restriction in the econometric software, this study grouped the 18 industrial sectors extracted from Economática Pro ${ }^{\circledR}$ into three economy sectors industry, commerce and others. Because of the large ratio of companies from the industrial sector in the sample, industrial sector variables were not included in the regression models; consequently, this study was unable to assess their effects on working capital management.

\section{CONCLUSIONS}

The present study aimed to contribute to the understanding of short-term financial decisions by investigating the key factors of working capital management. It used a sample of 93 companies listed in São Paulo Stock Exchange (BOVESPA) for the period from 2001 to 2004, in a quarterly basis. After reviewing the existing literature, we found that few researchers have explored key factors of working capital by investigating several independent variables: industry characteristics, economic activities, operational process indicators, management monitoring mechanisms, company growth, company size, market power, debt level, among others. Their studies were conducted in many different countries with different economic situations, and they were based on different econometric models, leading to no clear consensus. Given the absence of mathematical models and specific, widely tested theories, we chose to explore the above mentioned key factors inspired on robust theories of corporate finance.

This study found evidence that companies with a high level of debt choose to work with lower levels of working capital, which was consistent with previous studies (CHIOU, CHENG and WU, 2006; NAZIR and AFZA, 2008). These findings corroborate the Pecking Order Theory and suggest that as companies increase their financial leverage, they tend to assume a more restrictive policy in working capital management in order to prevent capital consumption in accounts receivable and inventory and to avoid issuing new bonds and shares. This study did not find statistically significant evidence of the impact of proxies for management monitoring mechanisms on working capital management. Nevertheless, the relation between ownership concentration and annual compensation connected to profit was found to have a negative sign in most cases. This suggests that companies with large investors and compensation instruments can inhibit decisions involving excess of current assets beyond their operational needs.

The results regarding the impact of free cash flow on working capital management were contrary to our expectations, suggesting that companies with a low 
level of free cash flow have a higher level of working capital. A possible explanation can be the impact of company profitability on free cash flow measures. In this case, company profitability could affect working capital management. This proposition could be tested in future studies. With regard to the control variables, this study suggests that large companies and companies with high growth rates have lower working capital levels. A negative, significant relation with the variable days of accounts payable was also found, suggesting that smaller companies and companies with lower growth rates wait longer to settle their debts. Finally, no statistically relevant evidence was found to support that the dependent variable working capital management could be influenced by past behavior for the same variable.

This study found limitations which could be addressed in future studies. In order to increase knowledge about short-term investment and financing decisions, our suggestions are: to investigate alternative ways of measuring industry sector impact on working capital management; to study the impact of profitability as a key factor, as explained above; to find alternative proxies to measure management monitoring mechanisms, in spite of the limitations of public databases in Brazil; and, finally, to study the impact of external factors (interests, economic activity, credit volume, bankruptcy, risk, etc.).

\section{REFERENCES}

APPUHAMI, B. A. R. The impact of firms' capital expenditure on working capital management: an empirical study across industries in Thailand. International Management Review, v.4, n.1, p. 11-24, 2008.

ASSAF NETO, A; SILVA, C. A. T. Administração de capital de giro. 2ed. São Paulo: Atlas, 2002.

BALTAGI, B. Econometrics. 4ed. New York: Springer, 2008.

BECHT, M; BOLTON, P; ROELL, A. Corporate governance and control. In: CONSTANTINIDES, G; HARRIS, M; STULZ, R. Handbook of the economics of finance. New York: North Holland, 2003.

BREALEY, R. A; MYERS, S. C; ALLEN, F. Principles of corporate finance. 8nd ed. EUA: McGraw-Hill, 2008.
BRIGHAM, E.F; EHRHARDT, M. C. Financial management: theory and practice. 10 th. Melbourne: Thomson Learning, 2002.

CHEN, J. J. Determinants of capital structure of Chinese-listed companies. Journal of Business Research, v 57, n. 12, p. 1341-1351, 2004.

CHIOU, J, CHENG, L; WU, H. The determinants of working capital management. The Journal of American Academy of Business, Cambridge, v.10, n.1, p.149-155, 2006.

CHUNG, R; FIRTH, M; KIM, J. FCF agency cost, earnings management, and investor monitoring. Corporate Ownership and Control, v.2, n.4, 2005.

DELOOF, M. Does working capital management affect profitability of Belgian firms? Journal of Business Finance $\mathcal{E}$ Accounting, v.30, n.3, p.573 - 587, 2003.

EASTERBROOK, F. H. Two agency-cost explanations of dividends. The American Economic Review, v.74, n.4, p. 650-659, 1984.

FAMA, E. F; JENSEN, M. C. Separation of ownership and control. Journal of Law \& Economics. v. 26, n. 2, p. 30125, 1983 .

FAMA, E. F. Agency problems and the theory of the firm. Journal of Political Economy, v. 88, n. 2, p. 288-307, 1980.

FILBECK, G; KRUEGER T. An analysis of working capital management results across industries. Mid-American Journal of Business, v.20, n.2, p.11-18, 2005 .

FLEURIET, M; KEHDY, R; BLANC, G. O modelo Fleuriet: a dinâmica financeira das empresas brasileiras. 3ed. Rio de Janeiro: Campos. 2003.

GARCIA-TERUAEl, P. J; MARTINEZ-SOLANO, P. M. Effects of working capital management on SME profitability. International Journal of Managerial Finance, v.3, n.2, p. 164-177, 2007.

GITMAN, L. J. Princípios de administração financeira. 7. ed. São Paulo: Harbra, 1997.

GRAHAM, J.R; HARVEY, C. R. The theory and practice of corporate finance: evidence from the field. Journal of Financial Economics, v.60, n. 2, p. 187-243, 2001. 
HAWAWINI, G; VIALLET, C; VORA, A. Industry influence on corporation working capital decisions. Sloan Management Review, v.27, p.15-24, 1986.

HILL, M. D; KELLY, G. W; HIGHFIELD, M. J. Net operating working capital behavior; a first look. Financial Management, v. 39, n. 12, p.784-805, 2010.

JENSEN, M; MECKLING, W. Theory of the firm: managerial behavior, agency costs and ownership structure. Journal of Financial Economics, v.3, n. 4, 305-360, 1976.

JENSEN, M. Agency costs of free cash flow, corporate finance, and takeovers. The American Economic Review, v.76, n.2, p.323-329, 1986.

JENSEN, M. Self-interest, altruism, incentives, \& agency theory. Journal of Applied Corporate Finance, v.7, n.2, p.1-16, 1994.

KIESCHNICK, R; LAPLANTE, M; MOUSSAWI, R. Corporate working capital management: determinants and consequences et al. Working paper, 2006. Available in: http://www.fma.org/SLC/Papers/cwcmf_fma.pdf. Access in 22.04.2009.

KIM, Y. H; SRINIVASAN, V. Advances in working capital management: a research annual. Greenwich, EUA: Jai Press, 1991, v.2

KOSHIO, S. Nivel de caixa de empresas não financeiras no Brasil: determinantes e relação com o endividamento. Tese de Doutorado em Administração de Empresas, Escola de Administração de empresas de São Paulo da. Fundação Getúlio Vargas, São Paulo, 2005.

LAMBERSON, M. Changes in working capital of small firms in relation to changes in economic activity. American Journal of Business, v.10, n.2, p.45-50, 1995.

LAZARIDIS, I; TRYFONIDIS, D. Relationship between working capital management and profitability of listed companies in the Athens stock exchange. Journal of $\mathrm{Fi}$ nancial Management and Analysis, v.19, n.1, p. 26-35, 2006.

LEHN, K; POULSEN, A. Free cash flow and stockholder grains in going private transactions. Journal of Finance, v. 44, n. 3, p. 771-787, 1989.
LOPES, F. R. S. A visão integrada da administração do capital de giro aplicada às micro e pequenas empresas. 2005. 143p. Dissertação de Mestrado em Ciências Contábeis e Financeiras. Pontifícia Universidade Católica de São Paulo, São Paulo, 2005.

MARQUES, J. A. V. C; BRAGA, R. Análise dinâmica do capital de giro: o modelo Fleuriet. RAE-Revista de Administração de Empresas, v.35, n.3, p.49-63, 1995.

MCMAHON, R. G. P. Financial slack amongst manufacturing SMEs from Australia's business longitudinal survey: an exploratory study. Small Enterprise Research, v. 14, n.1, p.14-38, 2006.

MESQUITA, G. B. Gestão de capital de giro: uma aplicação do modelo Fleuriet a empresas argentinas, brasileiras, chilenas e mexicanas. 2008. 239 p. Dissertação de Mestrado em Administração de Empresas, Pontifícia Universidade Católica do Rio de Janeiro, Rio de Janeiro, 2008.

MYERS, S. C; MAJLUF, N. S. Corporate financing and investment decisions when firms have information that investors do not have, Journal of Financial Economics, v.13, n. 2, p.187-221, 1984.

NAKAMURA, W. T; MARTIN, D. M. L; FORTE, D; CARVALHO FILHO, A. F; COSTA, A. C. F; AMARAL, A. C. Determinantes de estrutura de capital no mercado brasileiro: análise de regressão com painel de dados no período 1999-2003. Revista Contabilidade E Financas, v.18, n. 44, p.72-85, 2007.

NAZIR, M. S; AFZA, T. On the factor determining working capital requirements. Proceedings of ASBBS, v.15, n.1, p.293-301, 2008. Available in: http://asbbs.org/files/2008/ PDF/N/Nazir.pdf. Access in 22.04.2009.

NUNN, K. P. The strategic determinants of working capital: a product -line perspective. The Journal of Financial Research, v.4, n.3, p.207-219, 1981.

PEDERSEN, T; THOMSEN, S. European patterns of corporate ownership: a twelve-country study. Journal of International Business Studies, v.28, n.4, p.759-778, 1997.

RAHMAN, A. F; MOHD-SALEH, N. The effect of free cash flow agency problem on the value relevance of earnings and book value. Journal of Financial Reporting \& Accounting, v.6, n.1, p.75-90, 2008. 
SATHYAMOORTHI, C. R; WALLY-DIMA, L. B. Working capital management: the case of listed retail domestic companies in Botswana. The Icfaian Journal of Management Research, v. 7, n.5, p.7-24, 2008.

SEBRAE. Fatores condicionantes e taxa de mortalidade das micro e pequenas empresas 2005: volume III. Brasília, 2007. Available in http://www.biblioteca.sebrae. com.br/.

SHIN, H. H; SOENEN, L. Efficiency of worlcing capital management and corporate profitability. Financial Practice and Education, Fall / Winter, v. 8, n. 2, p.37-45, 1998.

SIQUEIRA, T. V. Concentração da Propriedade nas Empresas Brasileiras de Capital Aberto. Revista do BNDES. Rio de Janeiro, v. 5, n. 10, p.37-62, 1998.

SMITH, R. L; KIM, J. The combined effects of free cash flow and financial slack on bidder and target stock returns. Journal of Business, v.67, n.2, p.281-310, 1994.

SMITH, K. V. State of the art of working capital management. Financial Management, v. 2, n. 3, p..50-55, 1973.

TIROLE, J. The Theory of Corporate Finance. 1. ed. Princeton: Princeton University Press, 2005.

WEIR, C; LAING, D. Ownership structure, board composition and the market for corporate control in the UK: an empirical analysis. Journal of Applied Economics, v. 35, Issue 16, p. 747-1759, 2003.

WOOLDRIDGE, J. M. Econometric analysis of cross section and panel data. Cambridge, Mass: The MIT Press, 2002. 